\title{
Chapter 21 \\ Diaspora Policies, Consular Services and Social Protection for Dutch Citizens Abroad
}

\author{
Joost Jansen and Robbert Goverts
}

\subsection{Introduction}

In this chapter, we aim to provide an overview of the Dutch diaspora policy infrastructure and key policies (e.g. cultural, economic, and political) implemented in the Netherlands. This chapter is predominantly based on publicly available information on various websites of the Ministry of Foreign Affairs, as well as informal interviews with officials from the Ministry. The chapter is structured as follows. First, we present some key characteristics of the (history of the) Dutch diaspora and a discussion about a recent controversy over dual citizenship, which together provide a context for the architecture of diaspora engagement policies in the Netherlands. More specifically, a political climate that prioritizes immigration policies and appeals to individual responsibility provides the context in which the Dutch Government engages with Dutch citizens living abroad. Next, we present a short overview of the Dutch diaspora infrastructure, followed by a discussion about the extent to which the Dutch Government engages with its citizens abroad. In what follows, we discuss the degree to which the Netherlands employs social protection policies that aim to provide assistance to Dutch nationals residing abroad. We conclude this chapter by discussing how this chapter's findings can be situated within the broader Dutch social and political climate and theoretical perspectives on policies of emigration.

J. Jansen $(\triangle) \cdot$ R. Goverts

Department of Public Administration and Sociology, Erasmus University Rotterdam,

Rotterdam, the Netherlands

e-mail: jansen@essb.eur.nl; goverts@essb.eur.nl 


\subsection{Diaspora Policy Infrastructure and Key Policies}

\subsubsection{The Dutch Diaspora and Its Relations with the Homeland}

While the Netherlands can be primarily typified as a typical (perhaps reluctant) 'country of immigration' preoccupied with managing immigration and immigrant integration (Hollifield et al. 2014), emigration has always been an important (and sometimes somewhat neglected) component of the Dutch migration history. The first decades following World War II were characterized by high levels of emigration and active interference by the Dutch Government (Van Dalen and Henkens 2007). The initial relief about the ending of World War II soon started to make place for concerns about the post-war reconstruction of the country, increasing unemployment and housing shortages, for which the Dutch Government did not have an immediate solution (Van Dalen and Henkens 2008). According to Van Dalen and Henkens (2007, p. 41) this "belief that the Netherlands was overcrowded and faced the prospect of permanent unemployment" led to a period of governmentallyinduced 'planned migration' (Petersen 1955). Active emigration policies of the Dutch Government caused an exodus of native-born Dutch to Canada, Australia and the United States. In the 1950s, about 125,000 Dutch emigrants settled in Canada, 100,000 in Australia and 50,000 in the United States (Nicolaas and Sprangers 2005). Research shows that, at that time, (social) after-care for native-born emigrants was not seen as a Dutch responsibility by the Dutch Government (Walker-Birckhead 1988).

The central question of this chapter is to what extent the Dutch Government nowadays actively interferes with the lives of Dutch nationals residing abroad. The past decades show an upward trend in the emigration level among Dutch nationals (Nicolaas and Sprangers 2005; Van Dalen and Henkens 2007; CBS 2018). Until today, Canada, Australia and the United States continue to count large numbers of Dutch emigrants (Van Dalen and Henkens 2007). Canada, for instance, hosts approximately 99,000 Dutch citizens (OECD 2015). Next to the traditional emigration countries in which large numbers of Dutch citizens reside, new popular countries of destination among Dutch emigrants are Belgium and Germany. In comparison, while in the 1950s, only 3000 and 2000 Dutch citizens emigrated to Belgium and Germany, respectively, their numbers had more than doubled in 2003 (Nicolaas and Sprangers 2005). Recent figures (OECD 2015) show that approximately 135,000 Dutch nationals live in Germany and roughly 110,000 in Belgium. Furthermore, research indicates that relatively highly educated Dutch nationals have a higher probability to emigrate (Van Dalen and Henkens 2007, 2013; OECD 2015).

Before discussing the Dutch diaspora infrastructure in the next section, we first want to address a contextual factor that, although perhaps not directly influencing current social policies of the Dutch Government aimed at its citizens abroad, might be indicative of the relatively moderate degree of active engagement with Dutch nationals living abroad (which forms the central conclusion of this chapter) 
compared to some other European countries discussed in this book. In 2011, the Dutch Government expressed a wish to further restrict the already relatively restrictive policy on dual citizenship, which caused an outburst of major public and political controversy. The proposed further restrictions of dual citizenship policy entailed removing some of the exceptions to the renunciation of their previous citizenship for immigrants who wish to acquire Dutch citizenship; vice versa, Dutch nationals who wish to acquire the citizenship of another country automatically lose their Dutch citizenship (Vink et al. 2019). According to the Dutch Bureau of Statistics, over $60 \%$ of the Dutch population were supportive of such a further restriction of dual citizenship (CBS 2011). The then widely supported negative stance towards dual citizenship in the Netherlands should primarily be understood within the context of, as noted by Vink et al. (2019, p. 97), "intolerance towards dual citizenship for immigrants, but to tolerance of such a status among Dutch natives abroad". However, the consequences of implementing strict dual nationality policies would have been enormous for the Dutch diaspora, as some of them risked being stripped of their Dutch nationality. Eventually, a successful lobby of the Dutch emigrant community made that the proposal was abandoned. Vink et al. (2019, p. 91) argue that this episode shows "the significant political cloud of the Dutch diaspora in dual citizenship legislation."

Although the prospect of (dual) nationals losing their Dutch citizenship was averted, we would argue that this episode could be interpreted as being illustrative of a more general climate of moderate active engagement with the Dutch diaspora abroad. As we shall see in the remaining sections of this chapter, we believe that two factors, namely i) a political context that prioritizes managing immigration and immigrant integration (rather than emigration) and ii) a growing appeal to the individual responsibility and self-reliance of Dutch citizens, together provide a context in which extensive governmental policies aimed at engaging with the social protection of Dutch nationals abroad appear to be relatively limited. In the following sections, we will discuss the key characteristic of the diaspora policy infrastructure and the key policies implemented in the Netherlands.

\subsubsection{Diaspora Infrastructure}

In the Netherlands, consular matters fall under the responsibility of the Consular Affairs and Visa Policy Department (DCV), which is one of the clusters of foreign policy areas, or themes, installed and directed by the Dutch Ministry of Foreign Affairs (founded in 1798). Worldwide, the Kingdom of the Netherlands (i.e. the Netherlands, Aruba, Curacao, and Sint Maarten) holds approximately 140 diplomatic posts, such as embassies and consulates. While not formalised in official policy documents, officials from the Ministry stated that in some cases, such as in Australia, mobile consular services are offered to citizens residing in geographic areas that are not located in the vicinity of an embassy or consulate. Furthermore, it should be noted that there are no institutions separate from the ministries dedicated 
to addressing the needs of Dutch nationals abroad, nor do there exist officially recognized representative or consultative institutions by which Dutch citizens residing abroad can be represented or through which Dutch nationals can address their questions of interest. Similarly, we found that Dutch political parties have no departments within their organizations that are dedicated to dealing with Dutch nationals residing abroad.

Another typical feature of the Dutch diaspora policy infrastructure is that it does not offer country specific policies for its nationals abroad. For example, the Ministry of Foreign Affairs or DCV have not developed diaspora policies that specifically target Dutch nationals residing in one of the top five countries were Dutch citizens abroad live (in decreasing order of absolute numbers: Germany, Belgium, Canada, the United States, Australia). Only for Dutch nationals living and working in Germany and Belgium, there is a website ${ }^{1}$ that provides tailored information on issues such as taxes, social insurance, and health insurance. This website is a joint initiative of the Ministries of Finance and Social Affairs, the tax authorities, the Social Insurance Bank, and the Employee Insurance Agency. However, it should be noted that the website is not managed by (a department of) the Dutch Ministry of Foreign Affairs. The information provided originates from the institutions, which are also listed under section II of this chapter, and that are responsible for the various domains of social protection.

\subsubsection{Key Engagement Policies}

On its website, DCV (Government 2019) states that it "offers citizens, businesses and government high-quality consular services. It is also responsible for visa policy and visa-related services. DCV serves as a safety net for Dutch interests abroad and is the first point of contact for nationals of other countries wanting to come to the Netherlands for personal or business reasons." However, as demonstrated in prior research (Vermeer-Künzli 2010, 507), "the Dutch legal order does not recognize any right to either consular assistance of diplomatic protection." Moreover, the Dutch Government "considers that consular assistance often is a matter of tailored service" (Vermeer-Künzli 2010, 509). Legally, this means that the Ministry, embassies, and consulates have no obligations to assist Dutch nationals residing abroad. While not specifically aimed at nationals living abroad, but rather at nationals who stay abroad for shorter periods of time, the Ministry of Foreign Affairs always emphasizes the importance of a decent (travel) insurance, individual responsibility, and carefulness. The Ministry's advice points at the emphasis it places on the self-reliance of Dutch citizens. However, in practice, recent cases of emergency demonstrate a general willingness of the Dutch authorities to provide

\footnotetext{
${ }^{1}$ www.grensinfopunt.nl. Accessed 16 March 2020.
} 
consular assistance or services to Dutch citizens abroad who were in serious need (Kopinga 2018).

Informal interviews with officials from the Ministry and information on its websites indicate that DCV is primarily concerned with the provision of basic information, assistance, and services. Via an online portal specifically designed for Dutch nationals residing or working abroad, ${ }^{2}$ by phone via the '24/7 BZ Contact Centre', ${ }^{3}$ and via Twitter, ${ }^{4}$ the Ministry aims at streamlining the provision of information to Dutch nationals who live, work, study, travel, and do business abroad. Dutch nationals can ask questions about consular matters, like passports, other legal documents, and travel advice. Also, they can contact the 24/7 BZ Contact Centre in an emergency, for example, if they are admitted to a hospital abroad or lost their passport. Overall, the information provided at the online portal varies from renewing passports and identity cards, to information about voting in Dutch elections while residing abroad. Oftentimes, information on specific domains merely consists of referrals to other (public) organisations responsible for the domain in question. For instance, with regards to pensions and social benefits, the portal refers to the websites of the Social Insurance Bank and the Employee Insurance Agency, respectively.

\subsubsection{Engaging with Dutch Nationals Abroad}

In what follows, we will discuss in more detail to what extent the Dutch Ministry of Foreign Affairs engages with Dutch nationals abroad regarding electoral rights, repatriation, education, housing, return, and business.

Firstly, except for citizens residing in Aruba, Curaçao and Sint Maarten, Dutch citizens residing permanently abroad are allowed to vote for national elections and referenda while living abroad (also see Schrauwen 2013). Moreover, they are allowed to run as candidates for Upper and Lower House elections. While for provincial and municipal elections voting is not possible for Dutch citizens residing abroad, they can stand as candidates if they sign a declaration showing that, once elected, "they intend to take up residence in the relevant province or municipality" (Schrauwen 2013, p. 5). Having officially registered (online) as a voter, voting is possible in numerous ways. Dutch nationals abroad can vote either by post, by proxy, or by casting their ballot in the Netherlands.

Secondly, regarding repatriation to the Netherlands, no official policies exist. Although consular services and obligations are set down in the 1968 Consular Relations Act, which gave effect to the Vienna Convention on Consular Relations, consular assistance in the Netherlands is based on policy and not legal right. Therefore, the Netherlands is under no legal obligation to provide consular

\footnotetext{
${ }^{2}$ www.netherlandsworldwide.nl. Accessed 16 March 2020.

${ }^{3} 24 \mathrm{~h}$ a day, 7 days a week on +31247247247 .

$4 @ 247 \mathrm{BZ}$.
} 
assistance. Assistance can only be provided ratione personae, that is, by reason of the person concerned. For example, the Ministry of Foreign Affairs was partly responsible for the repatriation of the victims' remains and personal belongings of Dutch nationals who lost their lives in the MH17 crash in 2014. This example shows that, especially in exceptional cases of emergency, the Dutch Government is willing to provide extensive consular assistance.

Thirdly, with respect to Dutch education abroad, although not part of the Ministry of Foreign Affairs, the online portal refers to the Foundation for Dutch Education Worldwide, which is a network for Dutch education commissioned by the Ministry of Education, Culture and Science, that aims at promoting and supporting high standards of Dutch education for Dutch-speaking children around the world.

Lastly, the Ministry has not implemented any policies by which the Netherland (1) provides financial incentives to nationals residing abroad to purchase real estate in their home country; (2) encourages the return of citizens residing abroad to the home country; (3) facilitates or provides incentives to send remittances; or (4) provides incentives to invest in/create productive activities (i.e. business) in the Netherlands. Regarding the latter point, the Ministry states that it predominantly aims at promoting the interests of Dutch nationals who want to do business abroad.

\subsection{Diaspora Policies and Social Protection in the Netherlands}

As we already discussed in the previous section, the Dutch Government does not employ official and extensive policies that aim to address the social needs of Dutch nationals residing abroad. In interviews with officials from the Ministry, it was stressed that, to an important extent, the Ministry appeals to the individual responsibility and self-reliance of Dutch citizens. In this respect, the effective provision of reliable and good quality information is conceived as crucial. This finding resonates well with the broader changing political and policy climate in the Netherlands, from welfare state to 'participation society', 5 in which the Dutch Government increasingly emphasizes 'responsibilization' (see Van Houdt et al. 2011) and seeks to facilitate and empower its citizens rather than offering them a (strong) helping hand (Veldheer et al. 2012). While these transformations are often studied in relation to immigration and integration policies, we would argue that they could also help understand the extent to which Dutch diaspora policies are developed in the current political and social climate.

In light of such strong emphasis on individual responsibility, the Consular Affairs and Visa Policy Department (DCV), as a part of the Ministry of Foreign Affairs, is primarily concerned with offering information, assistance, and services, both online and offline, via the 24/7 Contact Centre. In the 2017 coalition agreement (Tweede

${ }^{5}$ The notion of participation society aligns well with its British counterpart "Big Society". 
Kamer 2017), the four government parties (VVD, CDA, D66, CU) announced to expand and strengthen the Dutch representation abroad by introducing a new digital counter, a so-called 'one stop shop', where Dutch nationals living abroad can navigate to for public services and products (e.g. passports). The objective of this digital counter is to centralise and facilitate the provision of tailored information and services (such as identity documents or life certificates).

Again, this underlines the idea that the Ministry is primarily concerned with streamlining the provision of information and basic services, and not so much with implementing policies or programmes that actively aim to provide social protection or assistance to Dutch nationals abroad. In the following section, we will discuss five social protection areas to which this Dutch Government perspective on the assistance of its citizens abroad by the Ministry of Foreign Affairs also applies.

\subsubsection{Unemployment}

As provided by the European Union (EU) legislation, an unemployed individual who receives unemployment benefits can leave the country to search for work in another EU Member State and continue to temporarily receive Dutch unemployment benefit. Other than referring to the Employee Insurance Agency (UWV), the Ministry of Foreign Affairs itself does not employ policies to assist unemployed Dutch nationals residing abroad in any way. The UWV is an autonomous administrative authority, commissioned by the Ministry of Social Affairs and Employment (SZW) to implement employee insurances and provide labour market and data services. The extent to which Dutch nationals residing abroad are entitled to claim unemployment benefits from countries of residence's unemployment insurance naturally entirely depends on one's particular situation (e.g. type of unemployment, living in an EU Member State or in a third country, being insured in the Netherlands or not, etc.).

\subsubsection{Health Care}

In general, the Ministry of Foreign Affairs has not implemented policies or programmes that aim at providing services to Dutch nationals living abroad in dealing with health risks. For instance, if Dutch nationals are unexpectedly admitted to a hospital in foreign countries, they are advised to call their insurers' emergency support centres. In case someone is not insured for medical treatment in a foreign country, the embassy can contact the family in the Netherlands to transfer money to the person in need. Typically, the Ministry does not offer financial support. Financial advances are rarely given, and only if the Dutch national abroad signs a declaration in which s/he promises to repay the advance loan (see also Vermeer-Künzli 2010, p. 514). 


\subsubsection{Pensions}

The Ministry of Foreign Affairs itself does not assists Dutch citizens residing abroad to access their home or host country pensions and old-age benefits. The Ministry only refers to the website of the Social Insurance Bank (SVB), the organisation that pays out pensions. However, the SVB asks from Dutch nationals living abroad to fill in a form about their personal situation once or twice a year, as well as to send the SVB an official life certificate (which can be provided by the Dutch embassy or consulate). As shown in volume 1 of this series (see the country chapter on the Netherlands by Pennings 2020), Dutch citizens residing abroad can continue receiving old-age pensions in their countries of residence. However, when residing outside the EU, the amount received can be reduced unless a bilateral social security agreement specifies otherwise.

\subsubsection{Family-Related Benefits}

In the case of accessing home country family-related benefits, the Ministry refers to the Social Insurance Bank, which is also responsible for paying out child benefits and national survivor benefits. Dutch nationals who start living abroad but continue to work in the Netherlands, can usually keep their Dutch child benefits. If they start working outside the Netherlands, however, their Dutch child benefits will normally stop. In case of national survivor benefits, the SVB will continue to pay the benefits after one starts living in a country with which the Netherlands has an agreement (e.g. EU and European Economic Area (EEA) countries).

\subsubsection{Economic Hardship}

From the interviews with officials from the Ministry of Foreign Affairs, as well as the information that is provided through the website of the Ministry, we did not find any indication for the existence of policies or programmes by which the Ministry of Foreign Affairs assists Dutch nationals residing abroad in accessing guaranteed minimum resources. The Ministry largely appeals to the individual responsibility of its citizens abroad. This is well in line with what Vermeer-Künzli (2010, p. 517) states, namely that "the information provided through the Ministry's website gives the impression that it is intended to warn Dutch nationals that the Dutch authorities will not give out money, cannot provide release from jail and assume that individuals travel wisely and well-prepared." 


\subsection{Conclusions}

In this chapter, we discussed the Dutch diaspora policy infrastructure and key policies implemented in the Netherlands. Based on publicly available information, our main conclusion is that, rather than actively providing its nationals abroad with assistance in various domains of social protection, the Dutch Ministry of Foreign Affairs conceives of itself mainly as a facilitator that provides consular assistance in cases of emergency on an ad-hoc basis. This conclusion was confirmed in interviews with officials from the Ministry and reflected in its online (e.g. effective information provision its website and introduction of 'one stop shop') and offline practices (e.g. repatriation of victims MH17).

In practice, these findings imply that the consular services provided to Dutch nationals abroad are limited to basic consular services and assistance, while also being discretionary in nature. With regards to key areas of social protection, such as health care and social benefits, the Ministry tends to refer to other organisations responsible for the domains in question. By itself, the Ministry does not provide additional services or assistance to Dutch citizens living abroad. In case of calamities or emergency situations, the Ministry, embassies, and consuls have discretion to decide whether or not to assist a Dutch national and, if so, in what way. This, however, is not formalised in the Dutch legal order (cf. Vermeer-Künzli 2010).

The Ministry's stance towards Dutch nationals living abroad could be understood in relation to the broader social and political context in which governmental policies aimed at engaging with the Dutch diaspora appear to be rather limited. In a broader theoretical light, as a typical 'country of immigration' (Hollifield et al. 2014), the Netherlands prioritized less its diaspora policies within the current political climate. Moreover, in line with an increasing neoliberal appeal to the individual responsibility and self-reliance of its citizens ('responsibilization'), the Dutch Government does not - that is, publicly - employ social protection policies concerning its nationals abroad. Therefore, the Dutch diaspora policy can, to a large extent, be characterized as 'non-policy as policy' or ad-hoc policy. Assistance and protection can be provided, but are not guaranteed.

In light of these findings, the Netherlands substantially differs from typical countries of emigration, such as Ireland, Mexico, the Baltic States, or Israel. These countries conceive of the development of successful diaspora policies that aim at maintaining links with their nationals abroad as pivotal in preserving cultural linkages, as well as mobilising the human capital and financial resources of their diaspora, the latter with the aim of fostering long-term economic growth in the home country (Engbersen and Jansen 2013). Not being a typical country of emigration, Dutch socio-economic diaspora policies seem to be fairly limited, and insofar as they exist, they are predominantly concerned with, for instance, exporting knowledge and starting businesses abroad (thereby appealing to the individual responsibility of its citizens), and not so much with areas of social protection. Given the upward trend in emigration levels among Dutch nationals and the fact that Dutch emigrants are likely to be relatively highly educated, we would argue that a more 
extensive diaspora infrastructure could potentially harness positive effects, such as the mobilization of economic and human capital.

Acknowledgements This chapter is part of the project "Migration and Transnational Social Protection in (Post)Crisis Europe (MiTSoPro)" that has received funding from the European Research Council (ERC) under the European Union's Horizon 2020 research and innovation programme (Grant agreement No. 680014). In addition to this chapter, readers can find a series of indicators comparing national social protection and diaspora policies across 40 countries on the following website: http://labos.ulg.ac.be/socialprotection/.

\section{References}

CBS. (2011). Brede steun voor beperking dubbele nationaliteit. https://www.cbs.nl/nl-nl/ nieuws/2011/18/brede-steun-voor-beperking-dubbele-nationaliteit. Accessed 13 Feb 2019.

CBS. (2018). Recordaantal immigranten en emigranten in 2017. https://www.cbs.nl/nl-nl/ nieuws/2018/42/recordaantal-immigranten-en-emigranten-in-2017. Accessed 13 Feb 2019.

Engbersen, G., \& Jansen, J. (2013). Emigration from the Baltic States: Economic impact and policy implications. In Coping with emigration in Baltic and east European countries. Paris: OECD Publishing. https://doi.org/10.1787/9789264204928-4-en.

Government. (2019). Policy theme departments. www.government.nl/ministries/ministry-of-foreign-affairs/organisational-structure/policy-theme-departments. Accessed 13 Feb 2019.

Hollifield, J., Martin, P. L., \& Orrenius, P. (2014). Controlling immigration: A global perspective. Stanford: Stanford University Press.

Kopinga, W. (2018, December 22). Duizenden Nederlanders jaarlijks in het buitenland in noord: wat doe je dan? https://nos.nl/artikel/2264629-duizenden-nederlanders-jaarlijks-in-hetbuitenland-in-nood-wat-doe-je-dan.html. Accessed 14 Feb 2019.

Nicolaas, H., \& Sprangers, A. (2005). Nederlanders over de grens. Demos, 21(4). https://www. nidi.nl/shared/content/demos/2005/demos-21-04-nicolaas.pdf. Accessed 13 Feb 2019.

OECD. (2015). Connecting with emigrants: A global profile of diasporas 2015. Paris: OECD Publishing. https://doi.org/10.1787/9789264239845-en.

Pennings, F. (2020). Migrants' access to social protection in the Netherlands. In J.-M. Lafleur \& D. Vintila (Eds.), Migration and social protection in Europe and beyond (volume 1). Comparing access to welfare entitlements (pp. to be added later). Cham: Springer.

Petersen, W. (1955). Planned migration: The social determinations of the Dutch-Canadian movement (Vol. 2). Berkeley: University of California Press.

Schrauwen, A. (2013). Access to electoral rights: Netherlands. Florence: European University Institute. http://cadmus.eui.eu/bitstream/handle/1814/29820/ER_2013_01_NetherlandsFRACIT.pdf?sequence=1. Accessed 18 Feb 2019.

Tweede, K. (2017). Vertrouwen in de toekomst. Regeerakkoord 2017-2021. VVD, CDA, D66 en ChristenUnie. https:/www.tweedekamer.nl/sites/default/files/atoms/files/regeerakkoord20172021.pdf. Accessed 13 Feb 2019.

Van Dalen, H. P., \& Henkens, K. (2007). Longing for the good life: Understanding emigration from a high-income country. Population and Development Review, 33(1), 37-66.

Van Dalen, H. P., \& Henkens, K. (2008). Waarom weg uit Nederland?: hedendaagse emigratie verklaard. Mens en Maatschappij, 83(3), 213-238.

Van Dalen, H. P., \& Henkens, K. (2013). Explaining emigration intentions and behaviour in the Netherlands, 2005-10. Population Studies, 67(2), 225-241. 
Van Houdt, F., Suvarierol, S., \& Schinkel, W. (2011). Neoliberal communitarian citizenship: Current trends towards "earned citizenship" in the United Kingdom, France and the Netherlands. International Sociology, 26(3), 408-432. https://doi.org/10.1177/0268580910393041.

Veldheer, V., Jonker, J., Van Noije, L., \& Vrooman, C. (2012). Een beroep op de burger. Minder verzorgingsstaat, meer eigen verantwoordelijkheid. Den Haag: Sociaal Cultureel Planbureau.

Vermeer-Künzli, A. (2010). The Netherlands. In S. Faro \& M. Moraru (Eds.), Consular and diplomatic protection: Legal framework in the EU member states (pp. 502-520). Florence: Ittig-Cnr.

Vink, M., Schmeets, H., \& Mennes, H. (2019). Double standards? Attitudes towards immigrant and emigrant dual citizenship in the Netherlands. Ethnic and Racial Studies, 42(16), 83-101.

Walker-Birckhead, W. (1988). Dutch identity and assimilation in Australia: An interpretative approach. Doctoral dissertation. https://openresearch-repository.anu.edu.au/handle/1885/112876. Accessed 14 Feb 2019.

Open Access This chapter is licensed under the terms of the Creative Commons Attribution 4.0 International License (http://creativecommons.org/licenses/by/4.0/), which permits use, sharing, adaptation, distribution and reproduction in any medium or format, as long as you give appropriate credit to the original author(s) and the source, provide a link to the Creative Commons license and indicate if changes were made.

The images or other third party material in this chapter are included in the chapter's Creative Commons license, unless indicated otherwise in a credit line to the material. If material is not included in the chapter's Creative Commons license and your intended use is not permitted by statutory regulation or exceeds the permitted use, you will need to obtain permission directly from the copyright holder. 